\title{
COPIM
}

\section{A Fork in the Road: OA Books and Visibility-Value in the Humanities}

Martin Paul Eve ${ }^{1}$

${ }^{1}$ Birkbeck, University of London

Published on: Jan 26, 2022

License: Creative Commons Attribution 4.0 International License (CC-BY 4.0). 
One of the great advantages of open access in the scientific disciplines is that the work of scientists can now be read by any interested party with internet access. While some readers will not be able to understand this, it is nonetheless easy for scientists to show their work. No longer must the public merely take on faith that scientists are doing their job. Instead, those publics can read the findings for themselves. There is selfevidential justificatory benefit for disciplines that make their research open.

Yet what of the humanities and social sciences? In these disciplines, the monograph plays a substantial role in the dissemination of research. But, frequently, these volumes are extremely expensive because they do not see huge print runs. Progress towards open access for book-length work remains frustratingly slow.

What we see emerging at this time, as a result, is a dual system in which all scientific research will be available to anyone to read, free of charge, while the most significant work in the humanities and social sciences will remain extremely expensive and less visible in the digital world.

This should be grave cause for concern. The humanities, in particular, face a perpetual crisis of value, in which these subjects are called to account for their existence and are asked to re-articulate their societal virtues. But the arguments grow thinner. How can the humanities parrot the oft-repeated liberal humanist line that they exist to produce an educated citizenry capable of participating critically in democracy, when most humanities work remains unreadable by most people? If we are approaching some kind of epistocracy - as Steven Connor has recently discussed it in his The Madness of Knowledge (2021) - it is not a humanistic form of knowledge-power by which we will be governed, but rather purely a scientific paradigm.

Learned societies in the humanities should be concerned (and they are). However, this concern should not be for the revenue streams that they feel are threatened by open access to journal subscriptions, but instead for the future of their disciplines in a world where they cannot justify themselves. When justifying oneself, pointing at a scholarly book that costs $£ 60$ is not the same as pointing to an article that can be read for free. The former mode assumes that the lay, impecunious reader should simply trust in experts to do their work and they will never have access. The latter model instead allows a citizenship to participate in its epistemic debates at no financial charge. The humanities are, as it stands, not allowing a general citizenship to partake in and of their research. The purpose of learned societies should be to defend our disciplines and to showcase the best of what we offer. OA offers an opportunity for learned 
societies better to undertake these actions. Indeed, one member of my family, a scientist by background, keeps abreast of all work in her field, despite her days in the academy being over. How many can say the same of past students in the humanities?

There are, of course, longstanding attempts to bring the humanities up to speed. There are now mandates from UKRI and other funders such as the Plan S group that hope to ensure that project-funded books are open from 2024. There will be a review of the UK's REF policies around open access in the coming months. But this is a long way from all books being open to all people. Projects like COPIM are attempting to ensure that the infrastructure for OA books is solid. Business models such as Opening the Future, MIT's Direct to Open, punctum books's and Open Book Publisher's respective membership programmes, are all intended to ensure a fair route to OA; one that avoids Book Processing Charges.

It is not too late to avoid the schism in which the humanities become even less visible compared to the sciences. But, as with climate change and as with pandemic viruses, if you don't act sooner than you would sometimes like, you will suffer the consequences later. We can pull humanities research back to equal public prominence with its scientific cousins. But our learned societies must embrace open access to help us to do so. "When you come to a fork in the road," said Yogi Berra in one of his famous aphorisms, "take it". While I must elide the humorous absurdity of Berra's original, I hope that the humanities will take the more hospitable path, at this fork.

Photo by Tom Parsons on Unsplash

\section{Citations}

1. Connor, S. (2021). The Madness of Knowledge: On Wisdom, Ignorance and Fantasies of Knowing. Reaktion Books. Retrieved from https://press.uchicago.edu/ucp/books/book/distributed/M/bo38336401.html $\triangleq$ 